\title{
Double-blind controlled trial of cimetidine in the healing of gastric ulcer
}

\author{
P. J. CIClitiRA ${ }^{1}$, R. J. MACHELL, M. J. G. FARTHING ${ }^{2}$, A. P. DICK, AND \\ J. O. HUNTER \\ From the Department of Medical Gastroenterology, Addenbrooke's Hospital, Cambridge
}

SUMMARY Sixty patients with gastric ulcers were treated for four weeks with either $1 \mathrm{~g}$ cimetidine per day or with identical tablets containing lactose. The healing rate, assessed by endoscopy, was 23 out of $35(66 \%)$ in the patients given cimetidine and 13 out of $25(52 \%)$ in those given placebo. The difference between the groups is not significant. During each of the four weeks of the study the cimetidine group experienced significantly fewer attacks of pain and consumed less antacids than the placebo treated patients.

The effectiveness of the histamine $\mathrm{H}_{2}$ antagonist cimetidine in duodenal ulcer is now well known. Its value in gastric ulcer has yet to be established. We report the results of a double blind trial of four weeks' treatment with cimetidine $1 \mathrm{~g}$ daily in the management of gastric ulcer.

\section{Method}

Patients admitted to the trial were ambulant and had been shown to have a gastric ulcer by fibreoptic gastroscopy within the previous four days. None had previously received cimetidine. At the beginning only patients considered unsuitable for treatment with carbenoxolone were included. These were either aged over 60 years, had a history of cardiovascular disease, or had already been unsuccessfully treated with carbenoxolone. After encouraging preliminary results, however, with $80 \%$ healing of the first ulcers studied (Ciclitira et al., 1976), it was decided to include patients who previously would have been treated with carbenoxolone. Any ulcer proximal to the pylorus was included in the study and all were brushed and biopsied to exclude malignancy.

Patients were allocated at random to receive either cimetidine $200 \mathrm{mg}$ tds and $\mathbf{4 0 0} \mathrm{mg}$ at night for four weeks, or identical tablets containing lactose. Both groups were supplied with unlabelled antacid tablets whose buffering capacity is $15.1 \mathrm{mmol}$ per tablet (Rennies, Nicholas Laboratories), to be taken whenever necessary for relief of ulcer pain. All other

${ }^{1}$ Drummond Research Fellow 1977-79.

'Present address: Wellcome Research Fellow, Department of Gastroenterology, St Bartholomew's Hospital, London EC1. Received for publication 12 February 1979 therapy was forbidden. Symptoms in the week before entering the trial were assessed by asking the patient to recall how many attacks of pain he had suffered. Subsequently all patients recorded on diary cards the number of attacks of pain suffered and the number of antacid tablets consumed. A return tablet count was made at each clinical visit to check that treatment had been correctly taken.

The patients were seen in outpatients after two weeks and at the end of the four week trial period. At these visits haemoglobin, white cell count, liver function tests, urea and electrolytes estimations were performed. At the end of the trial the endoscopy was repeated.

\section{Results}

Seventy patients entered the trial. Ten had to be withdrawn for various reasons including the subsequent discovery of malignancy in the biopsy (six) or default (two). In two cases (both on placebo) haemorrhage occurred within 48 hours of entry to the trial. These cases were all omitted from the final analysis. Clinical details of the remaining patients are shown on Table 1. Age, duration of symptoms, and smoking habits are comparable except that there were no female smokers in the placebo group.

Of the 60 patients who completed the trial, 35 received cimetidine and 25 placebo. In 23 out of 35 $(66 \%)$ receiving cimetidine the ulcers healed. In the placebo groups the figure was 13 out of $25(52 \%)$, $\chi^{2}$ was 0.64 , and $P>0.2$ by Fisher's exact test. The healing rate was not related to smoking habits.

The distribution of the ulcers is seen in Table 2 . There is no evidence that the site influenced healing. 
Table 1 Clinical details of patients in trial

\begin{tabular}{|c|c|c|c|c|c|c|c|}
\hline & \multicolumn{2}{|c|}{ Length of history ( $y r$ ) } & \multirow[t]{2}{*}{ Sex } & \multirow[t]{2}{*}{ No. } & \multicolumn{2}{|c|}{$\operatorname{Age}(y r)$} & \multirow[t]{2}{*}{ Smokers } \\
\hline & Mean & $\pm S D$ & & & Mean & $\pm S D$ & \\
\hline \multirow{2}{*}{\multicolumn{8}{|c|}{ Cimetidine }} \\
\hline & $7 \cdot 8$ & $9 \cdot 3$ & $\mathbf{F}$ & 4 & 63 & $11 \cdot 2$ & 2 \\
\hline & & & $\mathbf{M}$ & 8 & $57 \cdot 2$ & 14.5 & 6 \\
\hline \multirow{2}{*}{ Healed } & 4.9 & $6 \cdot 0$ & $\mathbf{F}$ & 9 & 59 & $7 \cdot 1$ & 6 \\
\hline & & & $\mathbf{M}$ & 14 & 54.5 & $8 \cdot 4$ & 8 \\
\hline \multirow{3}{*}{$\begin{array}{l}\text { Placebo } \\
\text { Non-healed }\end{array}$} & & & & & & & \\
\hline & 8.7 & $7 \cdot 7$ & $\mathbf{F}$ & 3 & $61 \cdot 3$ & $16 \cdot 6$ & 0 \\
\hline & & & $\mathbf{M}$ & 9 & 51.7 & 0.6 & 7 \\
\hline \multirow[t]{2}{*}{ Healed } & $8 \cdot 3$ & $11 \cdot 7$ & $\mathbf{F}$ & 4 & $71 \cdot 2$ & $8 \cdot 2$ & 0 \\
\hline & & & $\mathbf{M}$ & 9 & 54 & 10.9 & 4 \\
\hline
\end{tabular}

Table 2 Number of ulcers which healed compared with total number found at various positions in stomach

\begin{tabular}{llllll}
\hline & $\begin{array}{l}\text { Lesser } \\
\text { curve }\end{array}$ & $\begin{array}{l}\text { Posterior } \\
\text { wall }\end{array}$ & Pre-pyloric & $\begin{array}{l}\text { Greater } \\
\text { curve }\end{array}$ & $\begin{array}{l}\text { Anterior } \\
\text { wall }\end{array}$ \\
\hline $\begin{array}{l}\text { Cimetidine } \\
\text { Placebo }\end{array}$ & $19 / 28$ & $2 / 3$ & $3 / 5$ & $1 / 1$ & $2 / 2$ \\
\hline
\end{tabular}

Note:

Some patients had more than one ulcer

Two cimetidine patients had two ulcers and another had thi ee.

Two placebo patients had two ulcers and another had three.

Nine pre-pyloric ulcers were included in this study. As these sometimes behave differently from other gastric ulcers, the effect of cimetidine was reassessed when pre-pyloric ulcers had been excluded. There was still no significant improvement in ulcer healing, $\chi^{2}$ being $1 \cdot 15, \mathrm{P}>0 \cdot 2$.

Figures 1 and 2 show the mean number of attacks of pain per week and mean number of antacids consumed per week in the cimetidine and placebo groups. Figures 3 and 4 shows similar results when comparing healed versus non-healed patients. While the method for collecting the number of attacks of pain in the week before the study was without the use of diary cards, this is included to show the similarity of the groups before the study began. It can be seen that there is a reduction of attacks of pain and antacid consumption when the cimetidine and placebo groups are compared in each of the weeks of the study. These differences reach statistical significance when analysed by the Mann Whitney test of ranking significance as shown in Table 3. When the symptoms of healed versus non-healed ulcers are compared (Fig. 3) there is seen a reduction in symptoms in the healed group. This, however, only reaches statistical significance in weeks two and four. Similarly, the mean number of antacids consumed is seen to be less in the healed compared with the non-healed patients. This does not reach statistical significance in any of the weeks of the study.

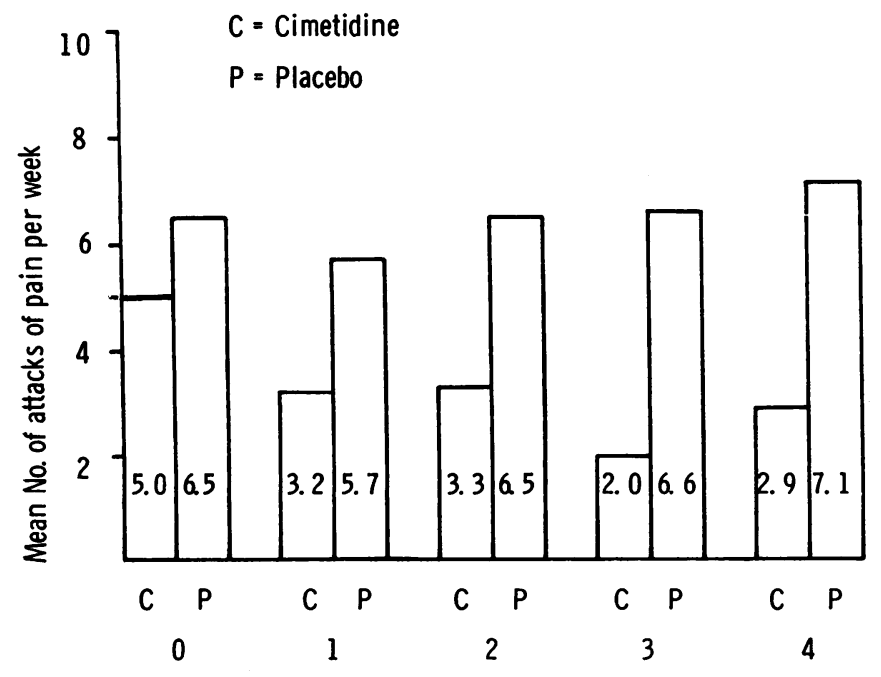

Fig. 1 Mean number of attacks of pain per week in cimetidine and placebo groups.

Weeks of study 


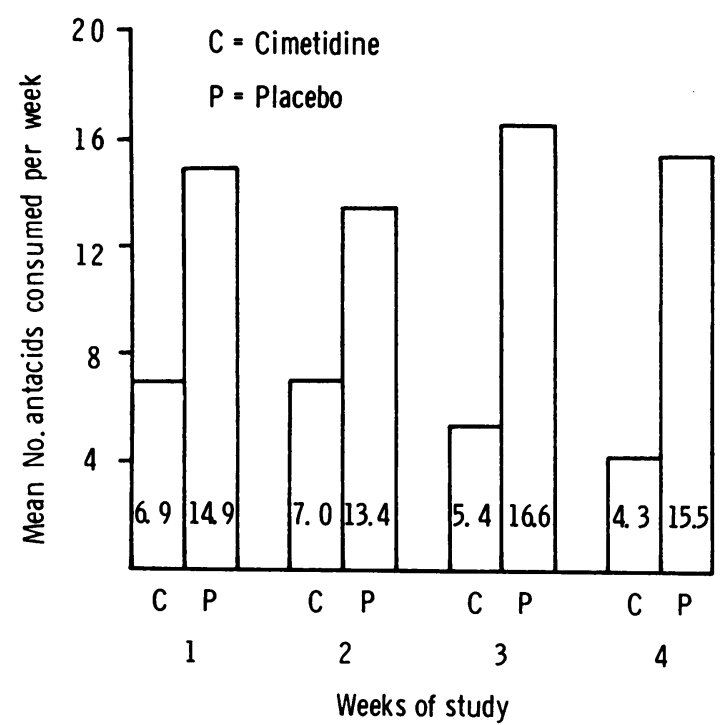

Fig. 2 Mean number of antacids consumed per week in cimetidine and placebo groups.
Haematological and biochemical parameters of the patients under study remained within normal limits. No patients experienced any important side-effects.

\section{Discussion}

Although the value of cimetidine in the management of duodenal ulcer has become apparent, there remains considerable doubt as to its efficacy in gastric ulcers. The trial has shown that the healed compared with the non-healed patients have suffered less attacks of pain in weeks two and four of the study, but have not consumed a significantly different number of antacids in any of the weeks of the study. The cimetidine compared with the placebo groups have, however, suffered less attacks of pain and consumed less antacids in all four weeks of the study. From this, it can be concluded that cimetidine is of value in the symptomatic treatment of gastric ulceration.

Table 4 summarises the results of trials of

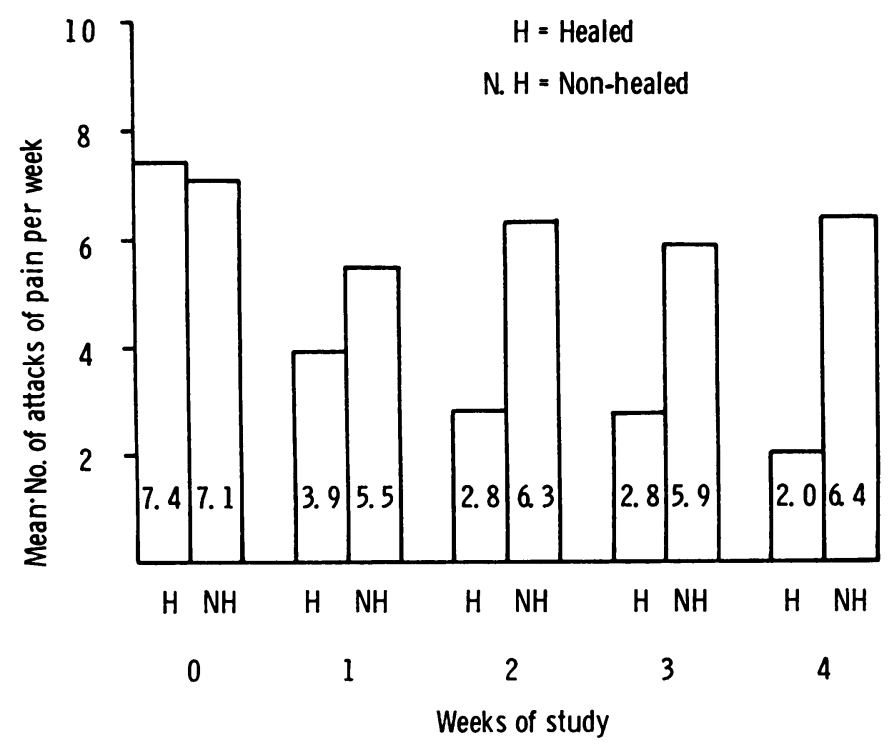

Fig. 3 Mean number of attacks of pain per week in healed vs non-healed groups.

Table 3 Value of approximate standard normal deviates using Mann Whitney ranking test comparing symptoms and antacid consumption in two groups: cimetidine versus placebo and healing versus non-healing ulcers

\begin{tabular}{|c|c|c|c|c|c|c|}
\hline \multirow[b]{2}{*}{$\begin{array}{l}\text { Symptoms } \\
\text { Antacid consumption }\end{array}$} & \multicolumn{5}{|c|}{ Weeks of study } & \\
\hline & $\begin{array}{l}0 \\
\text { NS } \\
-1 \cdot 020\end{array}$ & $\begin{array}{l}1 \\
-P<0.05 \\
-2.256 \\
P<0.01 \\
-2.609\end{array}$ & $\begin{array}{l}2 \\
P<0.05 \\
-2.467 \\
P<0.05 \\
-1.971\end{array}$ & $\begin{array}{l}3 \\
\mathbf{P}<0.01 \\
-3 \cdot 283 \\
\mathbf{P}<.01 \\
-3.283\end{array}$ & $\begin{array}{l}4 \\
P<.05 \\
-2.136 \\
P<0.01 \\
-3.141\end{array}$ & $\begin{array}{l}\text { Cimetidine versus } \\
\text { placebo }\end{array}$ \\
\hline $\begin{array}{l}\text { Symptoms } \\
\text { Antacid consumption }\end{array}$ & $\begin{array}{l}\text { NS } \\
-0.807\end{array}$ & $\begin{array}{l}\text { NS } \\
-1 \cdot 207 \\
\text { NS } \\
-1.682\end{array}$ & $\begin{array}{l}P<0.05 \\
-2.074 \\
\text { NS } \\
1.712\end{array}$ & $\begin{array}{l}\text { NS } \\
-1.878 \\
\text { NS } \\
-1.629\end{array}$ & $\begin{array}{l}P<0.01 \\
-2.550 \\
N S \\
-1.350\end{array}$ & $\begin{array}{l}\text { Healing versus non-healing } \\
\text { ulcers }\end{array}$ \\
\hline
\end{tabular}




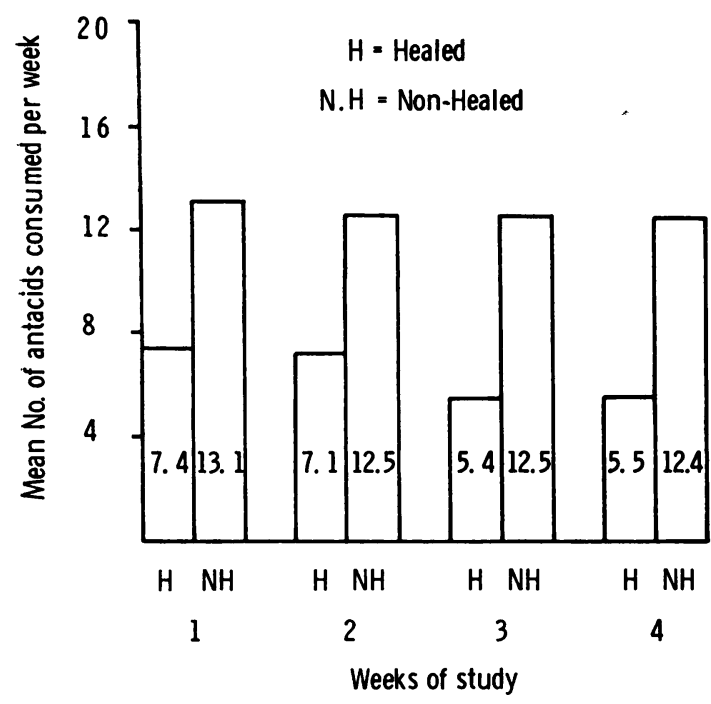

Fig. 4 Mean number of antacids consumed per week in healed and non-healed groups.

cimetidine in gastric ulcers so far; although two studies reported a significant improvement in the healing of gastric ulcers after cimetidine, two others have found, as we have, that there was no significant change. Table 4 shows that the percentage of gastric ulcers healing after cimetidine is fairly constant in all the trials at around $60-70 \%$. There are, however considerable differences in the rates of healing in the placebo groups, which vary from $27 \%$ (Frost et al., 1977) to $61 \%$ (Englert et al., 1978). The reason for the high placebo healing rate in our trial is not clear.

It has been suggested that concomitant antacid therapy may increase the rate of ulcer healing (Freston, 1978). While this may be true of the potent antacids used in some American studies (Dyck et al., 1978; Englert et al., 1978), those used by us were of weak buffering capacity, and mean antacid consumption was found to be highest in those patients whose ulcers failed to heal (Fig. 4). Although it is possible that our series included a higher proportion of acute gastric ulcers which might be expected to heal more easily, the mean length of ulcer history was similar to those reported by other investigators, and, indeed, the placebo patients tended to have longer histories than did those taking cimetidine.

It must be remembered that the spontaneous healing rate of gastric ulcers is known to be high, Gill (1947) observed healing in 20 patients with gastric ulcers treated by injection of distilled water alone, and more recently Scheurer et al. (1977) showed by endoscopy that over $83 \%$ of gastric ulcers healed after six weeks' treatment with simple placebo. In view of the high spontaneous healing rate in gastric ulcer, the use of cimetidine for the routine treatment of gastric ulcer remains controversiai.

We wish to thank Smith, Kline and French Laboratories, Welwyn Garden City, for supplies of cimetidine. Mr. R. Hanka (lecturer in statistics, University of Cambridge) for statistical advice; Sister P M Mountford and staff for invaluable assistance with endoscopy, and Mrs. S. R. Hanzl for secretarial assistance.

\section{References}

Bader, J. P., Morin, T., Bernier, J. J., Bertrand, J., Bétourné, C., Gastard, J., Lambert, R., Ribet, A., Sarles, H., and Toulet, J. (1977). Treatment of gastric ulcer by cimetidine a multicentre trial. In Cimetidine: Proceedings of the Second International Symposium on Histamine $\mathrm{H}_{2}$-Receptor Antagonists, pp. 287-292. Edited by W. L. Burland and M. A. Simkins. Excerpta Medica: Amsterdam.

Ciclitira, P. J., Machell, R. J., Farthing, M. J., Dick, A. P., and Hunter, J. O. (1976). A controlled trial of cimetidine in the treatment of gastric ulcer. In Cimetidine: Proceedings of the Second International Symposium on Histamine $\mathbf{H}_{\mathbf{2}}$ Receptor Antagonists. pp. 283-286. Edited by W. L. Burford and M. A. Simkins. Excerpta Medica: Amsterdam.

Doll, R., Hill, I. D., Hutton, C., and Underwood, D. J. U. (1962). Clinical trail of the triterpenoid liquorice compound in gastric and duodenal ulcer. Lancet, 2, 793-796.

Dyck, W. P., Belsito, A., Fleshler, B., Liebermann, T. R., Dickinson, P. B., and Wood, J. M. (1978). Cimetidine and placebo in the treatment of benign gastric ulcer. Gastroenterology, 74, 410-415.

Englert, E., Jr., Freston, J. W., Graham, D. Y., Finklestein, W., Kruss, D. M., Priest, R. J., Raskin, J. B., Rhodes, J. B., Rogers, A. I., Wenger, J., Wilcox, L. L., and Crossley, R. J. (1978). Cimetidine, antacid, and hospitaliza-

Table 4 Results of trials of cimetidine in gastric ulcers

\begin{tabular}{|c|c|c|c|c|c|}
\hline \multirow[t]{2}{*}{ Author } & \multirow[t]{2}{*}{ Patients (no.) } & \multirow{2}{*}{$\begin{array}{l}\text { Duration of } \\
\text { Treatment (Weeks) }\end{array}$} & \multicolumn{2}{|c|}{ Percentage healing } & \multirow[t]{2}{*}{ Significance } \\
\hline & & & Cimetidine & Placebo & \\
\hline $\begin{array}{l}\text { Bader et al. (1977) } \\
\text { Frost } \text { et al. (1977) } \\
\text { Dyck, et al. (1978) } \\
\text { Englert et al. (1978) } \\
\text { This study }\end{array}$ & $\begin{array}{l}53 \\
45 \\
59 \\
206 \\
60\end{array}$ & $\begin{array}{l}4 \\
6 \\
6 \\
6 \\
4\end{array}$ & $\begin{array}{l}69 \\
78 \\
60 \\
59(70)^{*} \\
66\end{array}$ & $\begin{array}{l}37 \\
27 \\
41 \\
61 \dagger \\
52\end{array}$ & $\begin{array}{l}\text { P }<0.02 \\
\text { P }<0.002 \\
\text { NS } \\
\text { NS } \\
\text { NS }\end{array}$ \\
\hline
\end{tabular}

$\$ 70 \%$ healing was achieved when cimetidine was given together with a powerful antacid, $59 \%$ when it was given alone.

$+61 \%$ healing was achieved when placebo tablets were given in conjunction with a powerful antacid. 
tion in the treatment of benign gastric ulcer. Gastroenterology, 74, 416-425.

Freston, J. W. (1978). Cimetidine in the treatment of gastric ulcer, Gastroenterology, 74, 426-430.

Frost, F., Rahbek, I., Rune, S. J., Birger Jensen, K., Gudmand-Høyer, E., Krag, E., Rask-Madsen, J., Wulff, H. R., Garbøl, J., Gotlieb Jensen, K., Højlund, M., Nissen, V. R. (1977). Cimetidine in patients with gastric ulcer; a multicentre controlled trial. British Medical Journal, 2, 795-799.

Gill, A. M. (1947). Pain and the healing of peptic ulcers. Lancet, 1, 291.

Scheurer, U., Witzel, L., Halter, F., Keller, H. M., Huber, R., and Galeazzi, R. (1977). Gastric and duodenal ulcer healing under placebo treatment. Gastroenterology, 72, 828-841. 